www.econa.org.ua

удк 330.3

JEL classification: D24, F20, 010

\section{Олексій ЗАДОРОЖНИЙ}

Національний технічний університет

України «Київський політехнічний інститут

ім. Ігоря Сікорського», Україна

E-mail: azadoroznyj963@gmail.com

https://orcid.org/0000-0002-4879-1230

https://publons.com/researcher/ABA-72972021/

\section{Ганна ЖАЛДАК}

кандидат економічних наук, доцент, кафедра менеджменту підприємств, Національний технічний університет України «Київський політехнічний інститут ім. Ігоря Сікорського» , Україна E-mail: ann17@i.ua https://orcid.org/0000-0003-3421-3648 https://publons.com/researcher/AAK-62442020/

(C) Олексій Задорожний, Ганна Жалдак, 2021

Отримано: 01.11.2021 p

Прорецензовано: 08.11.2021 p.

Рекомендовано до друку: 16.11.2021 р.

Опубліковано: 16.11.2021 p.

\section{(c) (1) (8)}

Ця стаття розповсюджується на умовах ліцензії Creative Commons AttributionNonCommercial 4. 0, яка дозволяє необмежене повторне використання, розповсюдження та відтворення на будь-якому носії, за умови правильного цитування оригінальної роботи.
Олексій Задорожний (Україна)

Ганна Жалдак (Україна)

\section{РОЗВИТОК КОМПАНІЙ В УМОВАХ НЕСТАБІЛЬНОСТІ СВІТОВОЇ ЕКОНОМІКИ: МОЖЛИВОСТІ, ВИКЛИКИ, ПЕРСПЕКТИВИ}

\author{
АНОТАЦІя
}

Економічні процеси, як відомо, мають циклічний характер, що визначає періоди активного економічного зростання та спадання. Ураховуючи динамічність світового господарства, основним завданням на сьогодні для представників малого, середнього та великого бізнесу $\epsilon$ адаптація до непостійних ринкових умов. Пристосування компаній до циклічних процесів $\epsilon$ єдиним шляхом до підвищення конкурентоспроможності фірми, максимізації прибутків, підвищення ефективності використання капіталу, тощо.

При проведенні дослідження використовувалися такі мікроекономічні методи, як: індуктивний, дедуктивний, статистичний, динамічний, тощо.

Метою дослідження було визначення позитивних й негативних ефектів нестабільності світової економіки на розвиток компаній різних галузей господарства.

Досліджено сучасні тенденції розвитку компаній за умов нестабільної економічної ситуації. Наведено приклади активного розвитку та банкрутства компаній за економічних криз, потрясінь, депресій,. Визначено вплив пандемії COVID-19 на становлення й розвиток окремих підприємств. Наведено статистичну інформацію щодо змін валового прибутку деяких компаній вторинного й третинного секторів господарства в умовах нестабільності ринку. Визначено ключові принципи зростання ефективності роботи підприємств, враховуючи циклічний характер економіки, зокрема: мінімізація витрат та досягнення вищого рівня екологічності виробництва; впровадження високого рівня інноваційності та розвитку технологічних інновацій; підвищення якості менеджменту, що забезпечить високий рівень гнучкості та адаптивності компаній до непередбачених змін; розвиток культури експериментування. Наведені приклади деяких інструментів й методів для аналізу зовнішнього та внутрішнього середовища компанії, зокрема, SWOT-аналіз, використання яких забезпечує можливість прийняття управлінських рішень для підвищення ефективності використання капіталу. Зроблено висновки, що за умов, коли конкуренція на ринку є сталою, або збільшується, проводиться так звана «боротьба за долар споживача», а отже компаніям необхідно постійно проводити аналіз власних конкурентів. Це дає змогу максимально швидко приймати відповідні рішення при зміні ринкових умов.

Задорожний О., Жалдак Г. Розвиток компаній в умовах нестабільності світової економіки: можливості, виклики, перспективи. Економічний аналіз. 2021. Том 31. № 3. С. 125-132.

DOI: https://doi.org/10.35774/econa2021.03.125

Ключові слова: криза; економічна нестабільність; компанія; розвиток; цифровізація; виробництво. 
UDC 330.3

JEL classification: D24, F20, 010

\section{Oleksii ZADOROZHNYI}

National Technical University of Ukraine "Igor Sikorsky Kyiv Polytechnic Institute", Ukraine

E-mail: azadoroznyj963@gmail.com https://orcid.org/0000-0002-4879-1230 https://publons.com/researcher/ABA-7297. 2021/

\section{Hanna ZHALDAK}

$P h D$ in Economics,

Associate Professor,

Department of Enterprise Management, National Technical University of Ukraine "Igor Sikorsky Kyiv Polytechnic Institute", Ukraine E-mail: ann17@i.ua

https://orcid.org/0000-0003-3421-3648 https://publons.com/researcher/AAK-62442020

(C) Oleksii Zadorozhnyi, Hanna Zhaldak, 2021

Received: 01.11.2021

Revised: 08.11.2021

Accepted: 16.11.2021

Online publication date: 16.11 .2021

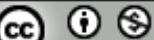

This is an Open Access article, distributed under the terms of the Creative Commons AttributionNonCommercial 4. 0 license, which permits unrestricted re-use, distribution, and reproduction in any medium, provided the original work is properly cited.
Oleksii Zadorozhnyi (Ukraine)

Hanna Zhaldak (Ukraine)

\section{DEVELOPMENT OF COMPANIES IN THE CONDITIONS OF INSTABILITY OF THE WORLD ECONOMY: OPPORTUNITIES, CHALLENGES, PROSPECTS}

\author{
ABStRACT
}

As we know economic processes have a cyclical nature, which determines the periods of active economic growth and decline. Given the dynamic development of the world economy, the main task today for small, medium and large businesses is to adapt to volatile market conditions. Adaptation of companies to cyclical processes is the only way to increase the level of competitiveness of the firm, maximize profits, increase the efficiency of capital use, and so on. During the research such general scientific methods as: inductive, deductive, statistical, dynamic, etc. are used. The aim of the study was to determine the positive and negative effects of the instability of the world economy on the development of companies in various sectors of the economy.

Current trends in the development of companies in an unstable economic situation are studied. Examples of active development and bankruptcy of companies during economic crises, shocks, depressions are given. The impact of the COVID-19 pandemic on the formation and development of individual enterprises is analyzed. The statistical information on changes in gross profit of some companies of the secondary and tertiary sectors of the economy in the conditions of market instability is given. The main principles of increasing the efficiency of enterprises, taking into account the cyclical nature of the economy, in particular: minimizing costs and achieving a higher level of environmental friendliness; introduction of a high level of innovation and development of technological innovations; improving the quality of management, which will provide a high level of flexibility and adaptability of companies to unforeseen changes; development of a culture of experimentation. Examples of some tools and methods for analyzing the external and internal environment of the company, in particular, SWOT-analysis, the use of which provides the ability to make management decisions to improve the efficiency of capital use. It is concluded that under conditions when competition in the market is constant or increasing, the so-called "struggle for the consumer's dollar" is carried out, and therefore companies need to constantly analyze their competitors. This allows you to make appropriate decisions as quickly as possible when market conditions change.

Zadorozhnyi, O., \& Zhaldak, H. (2021). Development of companies in the conditions of instability of the world economy: opportunities, challenges, prospects. Economic analysis, 31 (3), 125-132.

DOI: https://doi.org/10.35774/econa2021.03.125

Keywords: crisis; economic instability; company; development; digitization; production. 


\section{Вступ}

Як відомо, економічні процеси мають циклічний характер, що обумовлює існування періодів активного економічного зростання та спадання. У ринкових умовах світове господарство дедалі частіше зіштовхується 3 проблемами перевиробництва, постійного зростання конкуренції, що чинять негативний вплив на розвиток економіки країни загалом і окремих компаній зокрема. Так, перші крупні кризи почали відбуватися в Англії в XVII столітті, а найбільш відомими є Велика Депресія (1929-1933рр.), Фінансова криза (2007-2008 рр.). Світ і нині перебуває в складних умовах як для розвитку національних господарств, так і для окремих компаній, спричинених пандемією COVID-19. Зокрема, за даними Міжнародного валютного фонду (The International Monetary Fund), через запровадження карантину в більшості країн світовий ВВП за 2020 рік впав на 3,5\% [1]. Поряд із цим, економіка не має знаходитися постійно в стані спадання виробництва, в інтересах приватних компаній має бути збільшення чистих прибутків. Тому основним завданням для підприємств малого, середнього та великого бізнесу за умов економічної нестабільності $\epsilon$ адаптація до змін ринкових умов.

Серед основних досліджень даного напряму варто відзначити наукові публікації, економічні дослідження та прогнози Всесвітнього Економічного Форуму (The World Economic Forum) [2] Міжнародного валютного фонду (The International Monetary Fund) [3], основні наукові праці якого присвячені світовій перспективі економічного розвитку. Варто також відзначити таких науковців як: Наріман Бехравеш [4], Кеннет Рогофф [5], Крісталіна Георгієва [6], Клаус Шваб [7], які досліджували сучасну економічну нестабільність. Дослідженням кризових станів займалися Орловська О. В. [8], І. В. Кривов'язюк [9], Мельник А. О. [10]. Ураховуючи значний науковий доробок вітчизняних та закордонних вчених, все ж потребує подальших досліджень відповідь на питання, як компанії залишатися на ринку й максимально задовольняти диференційовані потреби споживачів в умовах кризових станів та нестабільності світової економіки.

\section{Мета та завдання статті}

Метою статті $\epsilon$ визначення можливостей, викликів та перспектив розвитку компаній в умовах нестабільності світової економіки. Для досягнення мети статті було поставлено та вирішено такі наукові завдання:
- визначити сутність кризи як джерела нестабільності та їі впливу на розвиток компаній;

- здійснити аналіз діяльності підприємств за умов нестабільності світової економіки;

- виокремити напрями розвитку компаній в умовах економічної нестабільності.

\section{Виклад основного матеріалу дослідження}

Економічна нестабільність виникає за умов, коли чинники, що впливають на економічний розвиток, виходять 3 рівноваги. Як відомо, дестабілізація економіки часто супроводжується зростанням інфляції, що, у свою чергу, може збільшити рівень безробіття серед населення, змінити структуру попиту й пропозиції на ринку, тощо. Компанії вимушені деформуватися, аби уникнути зменшення власних прибутків та утримувати позиції на ринках. Працівники уряду Сполучених Штатів Америки, проводячи дослідження щодо впливу криз на розвиток компаній та національних економік, у статті "Sometimes the world needs a crisis: Turning challenges into opportunities» [11], стверджують: «Кризи, як правило, розглядаються як небезпечні, дорогі та відволікають від інших завдань та пріоритетів. Однак огляд історії показує, що кризи та надзвичайні загрози можуть бути корисними для спрямування окремих людей, країни та навіть світу до вирішення проблеми»[11]. Орловська О. В. вважає, що криза «...дає можливість для роздумів над майбутнім, дає час для роботи над помилками у діях керівництва, перегляду програм розвитку, розробок майбутніх шляхів розвитку економіки країни» [12]. А прем'єр-міністр Великої Британії Вінстон Черчилль був переконаний, що будь-яка криза - це нові можливості [13].

Аналізуючи вищенаведене, зазначимо, що економічна нестабільність та кризи інколи можуть бути корисними для розвитку окремих компаній. За умов рецесії у світовій економіці підприємства вимушені впроваджувати нові технології та підходи до «завоювання» ринку. Фінансова криза 2007-2008 рр. дуже швидко набула глобальних форм, охопивши практично всі країни світу. Компанії одна за одною припиняли власну роботу через низьку рентабельність, деякі - збанкротували. Проте існує багато прикладів, що демонструють, як відомі нині підприємства виходили зі скрутного періоду після Світової фінансової кризи у 2008 році. Так, найбільша мережа супермаркетів в Іспанії «Mercadona», до якої нині входить понад 1635 магазинів, у 2007 році вимушена була впроваджувати інноваційні підходи заради утримання позицій на ринках та уникнення рецесії за умов глобального економічного занепаду. «Mercadona» впровадила «солідарний підхід до 
споживача», що базується на зниженні цін та стратегічному зменшенні витрат. Ці основні принципи надали можливість компанії вийти 3 кризи та стати найбільшим роздрібним підприємством Іспанії на сьогодні. Деякі інші компанії втілювали політику інтернаціоналізації та вдосконалення власних виробничих процесів. Зокрема, «Inditex» - іспанська компанія, світовий лідер з роздрібної торгівлі одягом, $€$ яскравим прикладом того, як збільшення ефективності виробництва, удосконалення системи франчайзингу та роздрібна торгівля в багатьох країнах світу допомогли закріпленню лідерства підприємства в певній галузі на світових ринках за умов економічної нестабільності. Нині у власності «Inditex» понад 7000 магазинів, що забезпечує працевлаштування близько 171000 робітників [14].

Незважаючи на те, що криза може служити каталізатором для розвитку, для деяких компаній рецесія в економіці може призвести до падіння виробництва та збуту, банкрутства, тощо. Так, індустріальний гігант "General Electric» зазнав значних збитків від Фінансової кризи у 2007-2008 рр. За один рік акції корпорації впали на 42\%. У 2009 році компанія скоротила річні дивіденди 3 1,24 до 0,82 доларів [15]. Тоді Федеральна резервна система США фактично виділила кредит для «General Electric» розміром \$16,1 млрд шляхом викупу корпоративних боргових зобов'язань [16]. У 2008 році Уоррен Баффет, один з найбільших та найвідоміших інвесторів світу, значно втрутився у стабілізацію «GE», інвестувавши в компанію \$3 млрд. Але різкого піднесення та виходу з Великої рецесії так і не відбулося. У 2015 році компанія придбала французьке транспортне підприємство «Alstom» вартістю \$9,5 млрд, що вважається одним з найбільших провалів. А вже у 2017 році ринкова капіталізація "General Electric» впала з \$262 млрд до \$107 млрд. У грудні 2018 року компанія скоротила дивіденди до найнижчого рівня - до 1 цента на акцію [15].

Іноді криза в середині окремої компанії, спричинена, зокрема, певною технологічною катастрофою, може буквально змінити весь світ. Так, у 2010 році бурова установка Deep Water Horizon вибухнула посеред Мексиканської затоки, спричинивши найбільший витік нафти у світовий океан за історію людства. Безконтрольний викид сирої нафти в океан тривав 87 днів, оскільки на той момент не існувало технічних методів оперативного вирішення даної проблеми, що, у свою чергу, спричинило безпрецедентну екологічну катастрофу. За кілька місяців була розроблена новітня технологія «Capping Stack», що допомогла покласти край катастрофі та нині використовується практично на всіх бурових установках світу [17]. Але відтепер компанії-видобувачі фактично $€$ більш захищеними від подібних вкрай несприятливих економічних (i екологічних) ситуацій, оскільки технологіям в даній галузі почали приділяти набагато більшої уваги.

За умов, коли в економіці спостерігається стрімке зменшення кількості продукту на ринках (наприклад, зменшення запасів автомобільного палива у Великій Британії, жовтень, 2021 р.), активно починають працювати компанії, кінцевим продуктом яких $€$ замінник дефіцитного товару. Так, у кінці вересня - початку жовтня 2021 р. в Європі різко підвищилася ціна на енергоносії - газ, вугілля, бензин, тощо [18]. Водночас у Великій Британії спостерігався катастрофічний дефіцит деяких робочих кадрів, зокрема, водіїв бензовозів, який посилювався через COVID-19, Brexit та ін. [19]. Цей ряд факторів спричинив нестачу палива на автозаправках. «Енергетична криза» у Великій Британії стала каталізатором для зростання попиту, зокрема, на електромобілі, які в даній ситуації слугують товаром-замінником [20]. У даному випадку національна нестача палива для споживчого ринку позитивно вплинула на розвиток однієї з гілок автомобілебудівної галузі. До того ж, глобальний перехід на автомобілі, що працюють за рахунок електричної енергії, позитивно впливає на екологію планети, зменшуючи викиди в атмосферу.

Інколи економічна криза може повністю деформувати ринки, кардинально змінивши попит споживачів на ті чи інші товари й послуги. Тоді компанії повинні трансформуватися й впроваджувати інноваційні технології, зокрема, проводити політику цифровізації для уникнення ряду економічних проблем. Пандемія, спричинена коронавірусною інфекцією COVID-19, різко збільшила попит на послуги з доставки їжі та інших товарів. Прибутки та ринкова вартість компаній 3 доставки в часи пандемії лише зростає, а це, у свою чергу, спричиняє велику зацікавленість з боку інвесторів. Наприклад, американський сервіс доставки продуктів «Instacart» оцінили вартістю в \$39 млрд. На сьогодні - це другий з найдорожчих стартапів у США [21]. Тоді як відома європейська компанія доставки «Glovo» залучила \$528 млн інвестицій [22]. Дані приклади демонструють, що за непередбачуваних умов переваги споживачів можуть доволі швидко змінюватися, а компанії, які найшвидше на це відреагували, отримують максимальні прибутки.

На фоні глобальної тенденції до цифровізації «ковідна рецесія» значно пожвавила розвиток ITіндустрії. За даними «Evans Data Corporation» у 2018 році у світі налічувалось 23,9 млн розробників програмного забезпечення, тоді як вже у 2021-му р. - 26,9 млн. Наприклад, ринок мобільних додатків на 2018 рік оцінювався у \$106,27 млрд і за прогнозами до 2026 року зросте до \$407,31 млрд 
[23]. Стрімке зростання даної галузі спричинене, зокрема, збільшенням попиту на споживчому ринку на дистанційні сервіси, он-лайн програми, мобільні додатки, тощо. Так, за 2021 фінансовий рік (який закінчився 31 січня 2021 р.) американський сервіс відео конференцій «Zoom Video Communications» збільшив власні доходи на $326 \%$ через різке зростання попиту на дистанційну роботу й освіту [24]. Промислові компанії за складних умов на світових ринках також стали втілювати політику цифровізації й автоматизації на підприємствах, оскільки це може значно збільшити ефективність виробничих процесів та зменшити амортизаційні витрати в середині фірми.

У результаті стрімкого поширення коронавірусної інфекції, окремі компаній разом із галузевими інститутами почали займатися розробкою вакцин різних типів проти COVID-19. Так, раніше збиткова німецька фірма «BioNTech», яка стала співрозробником М-РНК вакцини "Comirnaty» (більше відомої як «Pfizer»), за перше півріччя 2021 року отримала прибуток на рівні \$3,9 млрд, тоді як за перші 6 місяців 2020-го року «BioNTech» залишалася збитковою на рівні $-\$ 142$ млн. До кінця 2021 року компанія очікує доходи понад \$15,9 млрд. Науковий директор Інституту макроекономіки і дослідження кон'юнктури (IMK) в Дюссельдорфі Себастьян Дуллієн виступив із прогнозом щодо зростання загального ВВП Німеччини через стрімке збільшення доходної частини вищезгаданої компанії [25]. Такий ефект $€$ сприятливим до розвитку підприємств різних галузей національної економіки та матиме позитивне мікроекономічне значення.

Криза, спричинена пандемією, призвела до різкого збільшення попиту на медичні маски серед населення планети. Людство використовує понад 6,8 млн масок на день, це, у свою чергу, стало серйозним екологічним викликом, оскільки одним 3 компонентів для виготовлення масок $\epsilon$ поліпропілен, який має низьку здатність до розкладання. Науковці Королівського технологічного інституту в Мельбруні, Австралія, розробили технологію виробництва бетонної суміші 3 використанням подрібнених масок для дорожнього покриття, яку демонстрували світу в лютому 2021 року. Використання даної суміші може знизити загальні витрати на 30\%. [26]. Дані фактори, зокрема, можуть сприяти розвитку дорожньо-будівних компаній у перспективі.

На нашу думку, розвиток компаній в умовах економічної нестабільності, передусім має ґрунтуватися на:

- мінімізації витрат та досягненні вищого рівня екологічності виробництва. Так, згідно 3 дослідженням «McKinsey\&Company» [27], у вигляді опитування керівників компаній на тему «How digital reinventors are pulling away from the pack» у 2017 р., майже половина керівників оцінила зменшення витрат підприємства за умов економічної нестабільності як основну стратегію компанії;

- високому рівні інноваційності та розвитку технологічних інновацій. Цю тезу підтверджує опитування "How COVID-19 has pushed companies over the technology tipping pointand transformed business forever» [28] y 2020 p., де більшість респондентів вважає технологічні можливості як ключовий фактор успіху під час кризи.

- якості менеджменту, що забезпечить високий рівень гнучкості та адаптивності компаній до непередбачених змін. Зазвичай це спричинено скороченням часу, який необхідний управлінцям для отримання критичної інформації про бізнес та перерозподіл ресурсів для фінансування нових ініціатив.

- розвитку культури експериментування, яка у XXI столітті $\epsilon$ чи не найголовнішим фактором успішності компанії на ринку. Упровадження інноваційних технологій на виробництві або винайдення нових способів завоювання ринків завжди мають частину ризику, оскільки неможливо провести точний математичний аналіз, як дані нововведення сприймуть споживачі і, як наслідок, чи буте проект прибутковим для фірми. Зокрема, компанії «Nike» та «Gillette» експериментують 3 власними рекламними роликами, торкаючись політичних чи соціальних тем, що стає однією 3 причин збільшення прибутків. Та інколи інноваційні ведення на ринок можуть бути збитковими. Так, створення мобільного телефону "Amazon Fire» компанією «Amazon» не було позитивно сприйнято споживачами, унаслідок чого проект став збитковим, проте нині дана компанія продовжує впроваджувати інноваційні технології, не зупиняючись на одній поразці. Це дозволяє постійно розвиватися фірмі [29].

Зазначимо, що для прийняття «правильних» управлінських рішень в компанії, першочергово необхідно провести аналіз підприємства. М. Портер виділяє 5 основних факторів, що впливають на привабливість ринку: наявні конкуренти, потенційні конкуренти, взаємозамінні товари, постачальники, споживачі. Для аналізу конкуренції на ринку часто використовують модель Портера. Для оцінки сильних і слабких сторін фірми, зазвичай, проводять SWOT-аналіз [30]. Дані теоретичні моделі допоможуть зрозуміти загальні тенденції, що відбуваються на ринках, для прийняття рішень що сприятимуть зростанню ефективності використання капіталу компанії. 
www.econa.org.ua

\section{Висновки та перспективи подальших розвідок}

На основі проведеного вище ретроспективного аналізу, зазначимо, що криза, хоч і має загальне негативне значення для світового господарства, все ж таки дає можливості для розвитку як національних економік, так і окремих комерційних компаній. Якщо компанії $є$ інноваційно активними, мають високоякісний управлінський персонал, який здатний на перспективу моделювати різні мікроекономічні процеси та вчасно приймати правильні управлінські рішення, реалізовувати ефективну економічну політику, то кризові явища в економіці можуть стати рушієм до подальшого розвитку підприємства. Таким чином, економічна нестабільність створює певний «імунітет» для бізнесу, який визначається як відносна стійкість компанії на ринку та сприяє збільшенню швидкості та якості прийняття тих чи інших мікроекономічних рішень за умов різкої зміни економічної ситуації в країні чи світі задля уникнення збитків та утриманню рейтингової складової компанії на сприйнятному рівні.

Мікроекономічне моделювання кризових явищ, на основі аналізу циклічності економічного розвитку, прогнозуванні їх виникнення у майбутньому, дає можливість підприємствам приймати «правильні» рішення, що, у свою чергу, максимізуватиме прибутки компаній. Використання вищенаведених інструментів й методів оцінки економічної ситуації та становища фірми на ринку дає можливість збільшувати ефективність використання капіталу. Наведені чинники, зокрема, зменшення витрат, ефективні маркетингові комунікації, проведення інноваційної політики, тощо, можуть використовуватися як фундаментальні засади стратегічного розвитку компанії.

\section{СПИСОК ВИКОРИСТАНИХ ДЖЕРЕЛ}

1. МВФ: світовий ВВП впав на $3,5 \%$, у 2021 році зросте на 5,5\%. Finbalance. $2021 . \quad$ URL: https://finbalance.com.ua/news/mv f-polipshiv-prohnoz-zrostannyasvitovo-ekonomiki-v-2021-rotsi-do55\#: :text=\%D0\%9C\%D0\%92\%D0\% A4\%20\%D0\%BE\%D1\%86\%D1\%96\%D 0\%BD\%D1\%8E\%D1\%94\%20\%D1\%81 \%D0\%BA\%D0\%BE\%D1\%80\%D0\%BE \%D1\%87\%D0\%B5\%D0\%BD\%D0\%BD \%D1\%8F\%20\%D1\%81\%D0\%B2\%D1 \%96\%D1\%82\%D0\%BE\%D0\%B2\%D0 \%BE\%D0\%B3\%D0\%BE\%20\%D0\%92 \%D0\%92\%D0\%9F,(\%D0\%BD\%D0\%B 0\%200\%2C3\%20\%D0\%B2.

2. The Global Risks Report 2021. World Economic Forum. 2021. URL https://www.weforum.org/reports/ the-global-risks-report-2021.

3. Financial Crises, Investment Slumps, and Slow Recoveries. The International Monetary Fund. 2021. URL:

https://www.imf.org/en/Publication s/WP/Issues/2021/06/25/FinancialCrises-Investment-Slumps-andSlow-Recoveries-461271.

4. World Vs Virus podcast: An economist explains what COVID-19 has done to the global economy. World Economic Forum. 2020. URL: .https://www.weforum.org/agenda/ 2020/09/an-economist-explainswhat-covid-19-has-done-to-theglobal-economy.
5. Рейнхарт, Кармен М. та Кеннет С. Рогофф. 2014. "Відновлення після фінансової кризи: свідчення зі 100 серій". American Economic Review. URL:

https://www.aeaweb.org/articles? $d=10.1257 /$ aer.104.5.50.

6. COVID-19 sparked an economic crisis 'like no other' - but these measures can help now: WHO, IMF. World Economic Forum. 2020. URL: https://www.weforum.org/agenda/ 2020/04/who-briefing-0403economic-response-vulnerable/

7. Now is the time for a 'great reset' . World Economic Forum . 2020.URL: https://www.weforum.org/agenda/ 2020/06/now-is-the-time-for-agreat-reset.

8. Орловська О. В. Світові економічні кризи: причини виникнення, наслідки та шляхи подолання. Науковий вісник НлтУ України. 2015. Вип. 25.2. С. 197-202. URL: http://eadnurt.diit.edu.ua/jspui/bits tream/123456789/3957/1/Orlovska ,pdf.

9. Кривов'язюк І. В. Кризові явища в українській економіці та їх зв'язок 3 циклічністю. Економіка та держава. 2010. №12. C. 5-8. URL: http://www.economy.in.ua/pdf/12 2010/3.pdf
10. Мельник А. О. Світові економічні кризи в економіці України та їхнаслідки. Глобальні та національні проблеми економіки. 2014. №2. C.108-113. URL http://globalnational.in.ua/archive/2 2014/22.pdf.

11. Sometimes the world needs a crisis: Turning challenges into opportunities. Brookings. 2017. URL:

https://www.brookings.edu/researc $\mathrm{h} /$ sometimes-the-world-needs-acrisis-turning-challenges-intoopportunities.

12. Орловська О. В. Світові економічні кризи: причини виникнення, наслідки та шляхи подолання. Науковий вісник НЛтУ України. 2015. Вип. 25.2. С. 197-202. URL: http://www.irbis-nbuv.gov.ua/cgibin/irbis_nbuv/cgiirbis_64.exe?I21D $B N=L I N K \& P 21 D B N=U J R N \& Z 21 I D=\& S$ $21 \mathrm{REF}=10 \& S 21 \mathrm{CNR}=20 \& S 21 \mathrm{STN}=1 \&$ S21FMT =ASP_meta\&C21COM=S\&2 S21P03=FILA=\&2_S21STR=nvnltu_2 015_25.2_36.

13. Never Let a Good Crisis Go to Waste. FocusCFO. 2020. URL: https://focuscfo.com/never-let-agood-crisis-go-to-waste.

14. Weakness vs. opportunity: Companies that turned the crisis into their greatest ally. EAE business school. $2020 . \quad$ URL https://www.eae.es/en/news/eaenews/weakness-vs-opportunitycompanies-turned-crisis-theirgreatest-ally. 
15. The Rise and Fall of General Electric (GE). Investopedia. 2021. URL: https://www.investopedia.com/insi ghts/rise-and-fall-ge/\#2008-ge-incrisis

16. GE, JPMorgan got US Fed help in 2008: Records. The Indian Express. 2010. URL: https://indianexpress.com/article/n ews-archive/web/ge-jpmorgan-gotus-fed-help-in-2008-records/

17. How Science Stopped BP's Gulf of Mexico Oil Spill. Scientific American. 2011. URL: https://www.scientificamerican.co $\mathrm{m} /$ article/how-science-stopped-bpgulf-of-mexico-oil-spill/

18. Why Europe's energy prices are soaring and could get much worse. Euronews. 2021. https://www.euronews.com/2021/ 09/23/why-europe-s-energy-pricesare-soaring-and-could-get-muchworse

19. Прем'єр Британії: паливна криза зумовлена попитом, водії 3-за кордону - не вихід. Європейська правда. $2021 . \quad$ URL: https://www.eurointegration.com.u a/news/2021/10/3/7128556/

20. UK electric car inquiries soar during fuel supply crisis. The Guardian. 2021

https://www.theguardian.com/env ronment/2021/sep/27/uk-electriccar-inquiries-soar-fuel-supply-crisis
21. Instacart's valuation doubles to \$39 billion. CNBC. 2021. URL: https://www.cnbc.com/2021/03/02 /instacarts-valuation-doubles-to-39billion.html

22. Spain's Glovo picks up $\$ 528 \mathrm{M}$ as Europe's food delivery market continues to heat up. TechCrunch+ . 2021. URL: https://techcrunch.com/2021/03/3 $1 /$ spains-glovo-picks-up- $528 \mathrm{~m}$-asthe-food-deliver-market-continuesto-heat-up/

23. How Many Software Developers Are in the US and the World? Daxx. 2021. URL: https://www-daxxcom.cdn.ampproject.org/v/s/www. daxx.com/blog/developmenttrends/number-softwaredevelopers-

world/amp?amp_js_v=a6\&amp_gsa $=1 \&$ usqp=mq331AQKKAFQArABIIAC Aw\%3D\%3D\#aoh=16336751026561 \&referrer=https\%3A\%2F\%2Fwww.g oogle.com\&amp_tf=\%D0\%A1\%20\% D1\%81\%D0\%B0\%D0\%B9\%D1\%82\% D0\%B0\%20\%251\%24s\&ampshare=h ttps\%3A\%2F\%2Fwww.daxx.com\%2F blog\%2Fdevelopmenttrends\%2Fnumber-softwaredevelopers-world

24. За год доход Zoom вырос на $326 \%$ благодаря спросу на удаленную работу в условиях пандемии и самоизоляции. Forbes. 2021. URL: https://forbes.ua/ru/news/za-rikdokhid-zoom-zris-na-326-zavdyakipopitu-na-viddalenu-robotu-vumovakh-pandemii-i-samoizolyatsii02032021-1101
25. Фірма BioNTech, яка створила "вакцину Пфайзер", стала двигуном економіки ФPH. DW. 2021. URL: https://www.dw.com/uk/firmabiontech-iaka-stvoryla-vaktsynupfaizer-stala-dvyhunom-ekonomikyfrn/a-58859147

26. Австралійські вчені запропонували 3 одноразових масок робити дороги. Mind. 2021. URL:

https://mind.ua/news/20221826avstralijski-vcheni-zaproponuvali-zodnorazovih-masok-robiti-dorogi

27. How digital reinventors are pulling away from the pack McKinsey\&Company. 2017. URL: https://www.mckinsey.com/busines s-functions/mckinsey-digital/ourinsights/how-digital-reinventorsare-pulling-away-from-the-pack

28. How COVID-19 has pushed companies over the technology tipping point-and transformed business forever. McKinsey\&Company.2020. URL: https://www.mckinsey.com/busines s-functions/strategy-and-corporatefinance/our-insights/how-covid-19has-pushed-companies-over-thetechnology-tipping-point-andtransformed-business-forever

29. The Importance of Creating a Culture of Experimentation. RunRun.it. $2019 . \quad$ URL: https://blog.runrun.it/en/cultureof-experimentation/

30. Зозульов А. В., Кубишина Н. С. Маркетинг. Київ: Знання; Москва: Рибарі, 2011. С. 48-61

\section{REFERENCES}

1. IMF: world GDP fell by $3.5 \%$ in 2021 will grow by $5.5 \%$. Finbalance. (2021). Retrieved from: https://finbalance.com.ua/news/mv f-polipshiv-prohnoz-zrostannyasvitovo-ekonomiki-v-2021-rotsi-do55\#: :text=\%D0\%9C\%D0\%92\%D0\% A4\%20\%D0\%BE\%D1\%86\%D1\%96\%D 0\%BD\%D1\%8E\%D1\%94\%20\%D1\%81 \%D0\%BA\%D0\%BE\%D1\%80\%D0\%BE \%D1\%87\%D0\%B5\%D0\%BD\%D0\%BD \%D1\%8F\%20\%D1\%81\%D0\%B2\%D1 \%96\%D1\%82\%D0\%BE\%D0\%B2\%D0 \%BE\%D0\%B3\%D0\%BE\%20\%D0\%92 \%D0\%92\%D0\%9F,(\%D0\%BD\%D0\%B 0\%200\%2C3\%20\%D0\%B2.

2. The Global Risks Report 2021. World Economic Forum. (2021). Retrieved from:

https://www.weforum.org/reports/ the-global-risks-report-2021.

3. Financial Crises, Investment Slumps, and Slow Recoveries. The International Monetary Fund. (2021). Retrieved from: https://www.imf.org/en/Publication s/WP/Issues/2021/06/25/FinancialCrises-Investment-Slumps-andSlow-Recoveries-461271.

4. World Vs Virus podcast: An economist explains what COVID-19 has done to the global economy. World Economic Forum. (2020). Retrieved from: https://www.weforum.org/agenda/ 2020/09/an-economist-explainswhat-covid-19-has-done-to-theglobal-economy.
5. Reinhart, Carmen M., and Kenneth S. Rogoff. (2014). Recovery from Financial Crises: Evidence from 100 Episodes., 104 (5): 50-55. American Economic Review. Retrieved from: https://www.aeaweb.org/articles?i $\mathrm{d}=10.1257 /$ aer.104.5.50

6. COVID-19 sparked an economic crisis 'like no other' - but these measures can help now: WHO, IMF. World Economic Forum. (2020). Retrieved from: .https://www.weforum.org/agenda/ 2020/04/who-briefing-0403economic-response-vulnerable.

7. Now is the time for a 'great reset'. World Economic Forum. (2020). Retrieved from: https://www.weforum.org/agenda/ 2020/06/now-is-the-time-for-agreat-reset. 
8. Orlovska, A. (2015). Global Economic Crisis: Causes, Effects and Remedies. Scientific Bulletin of UNFU, 25(2), 197-202 [in Ukrainian].. Retrieved from: http://eadnurt.diit.edu.ua/jspui/bits tream/123456789/3957/1/Orlovska ,pdf.

9. Krivovyazyuk, I. (2010). Crisis phenomena in the Ukrainian economy and their connection with cyclicality. Economy and state, 12, 5-8 [in Ukrainian]. Retrieved from: http://www.economy.in.ua/pdf/12 2010/3.pdf.

10. Melnik, A. (2014). World economic crises in the economy of Ukraine and their consequences. Global and national problems of the economy, 2 108-113. [in Ukrainian]. Retrieved from: http://globalnational.in.ua/archive/22014/22.pdf.

11. Sometimes the world needs a crisis: Turning challenges into opportunities. Brookings. 2017 Retrieved from: https://www.brookings.edu/researc $\mathrm{h} /$ sometimes-the-world-needs-acrisis-turning-challenges-intoopportunities/

12. Orlovska, A. (2015). Global Economic Crisis: Causes, Effects and Remedies. Scientific Bulletin of UNFU, 25(2), 197-202 [in Ukrainian]. Retrieved from: http://www.irbisnbuv.gov.ua/cgi-

bin/irbis_nbuv/cgiirbis_64.exe?121D $B N=L I N K \& P 21 D B N=U J R N \& Z 21 \mid D=\& S$ 21REF $=10 \& S 21 C N R=20 \& S 21 S T N=1 \&$ $\mathrm{S} 21 \mathrm{FMT}=\mathrm{ASP}$ meta\&C21COM=S\&2 S21P03=FILA=\&2_S21STR=nvnltu_2 015_25.2_36

13. Never Let a Good Crisis Go to Waste. FocusCFO. 2020. Retrieved from: https://focuscfo.com/neverlet-a-good-crisis-go-to-waste/

14. Weakness vs. opportunity: Companies that turned the crisis into their greatest ally. EAE business school. 2020. Retrieved from: https://www.eae.es/en/news/eaenews/weakness-vs-opportunitycompanies-turned-crisis-theirgreatest-ally

15. The Rise and Fall of General Electric (GE). Investopedia. 2021. Retrieved from:

https://www.investopedia.com/insi ghts/rise-and-fall-ge/\#2008-ge-incrisis
16. GE, JPMorgan got US Fed help in 2008: Records. The Indian Express. 2010. Retrieved from: https://indianexpress.com/article/n ews-archive/web/ge-jpmorgan-gotus-fed-help-in-2008-records/

17. How Science Stopped BP's Gulf of Mexico Oil Spill. Scientific American. 2011. Retrieved from: .https://www.scientificamerican.co $\mathrm{m} /$ article/how-science-stopped-bpgulf-of-mexico-oil-spill.

18. Why Europe's energy prices are soaring and could get much worse. Euronews. (2021). Retrieved from: https://www.euronews.com/2021/ 09/23/why-europe-s-energy-pricesare-soaring-and-could-get-muchworse.

19. Prime Minister of the United Kingdom: the fuel crisis is due to demand, drivers from abroad - no way out. European truth. (2021). Retrieved from: https://www.eurointegration.com.u a/news/2021/10/3/7128556.

20. UK electric car inquiries soar during fuel supply crisis. The Guardian. (2021). Retrieved from: https://www.theguardian.com/envi ronment/2021/sep/27/uk-electriccar-inquiries-soar-fuel-supply-crisis.

21. Instacart's valuation doubles to $\$ 39$ billion. CNBC. (2021). Retrieved from:

https://www.cnbc.com/2021/03/02 /instacarts-valuation-doubles-to-39billion.htm

22. Spain's Glovo picks up $\$ 528 \mathrm{M}$ as Europe's food delivery market continues to heat up. TechCrunch+ . (2021). Retrieved from: https://techcrunch.com/2021/03/3 $1 /$ spains-glovo-picks-up-528m-asthe-food-deliver-market-continuesto-heat-up/

23. How Many Software Developers Are in the US and the World? Daxx. (2021). Retrieved from: https://www-daxx-

com.cdn.ampproject.org/v/s/www. daxx.com/blog/developmenttrends/number-softwaredevelopers-

world/amp?amp_js_v=a6\&amp_gsa $=1 \&$ usqp=mq331AQKKAFQArABIIAC Aw\%3D\%3D\#aoh=16336751026561 \&referrer=https\%3A\%2F\%2Fwww.g oogle.com\&amp_tf=\%D0\%A1\%20\% D1\%81\%D0\%B0\%D0\%B9\%D1\%82\% D0\%B0\%20\%251\%24s\&ampshare $=h$ ttps\%3A\%2F\%2Fwww.daxx.com\%2F blog\%2Fdevelopmenttrends\%2Fnumber-softwaredevelopers-world.
24. Over the year, Zoom's revenue grew by $326 \%$ due to the demand for remote work in a pandemic and self-isolation. Forbes. (2021). Retrieved from: https://forbes.ua/ru/news/za-rikdokhid-zoom-zris-na-326-zavdyakipopitu-na-viddalenu-robotu-vumovakh-pandemii-i-samoizolyatsii02032021-1101

25. BioNTech, which created the "Pfizer vaccine", became the engine of the German economy. DW. (2021). Retrieved from: https://www.dw.com/uk/firmabiontech-iaka-stvoryla-vaktsynupfaizer-stala-dvyhunom-ekonomikyfrn/a-58859147

26. Australian scientists have proposed to make disposable masks roads. Mind. (2021). Retrieved from: https://mind.ua/news/20221826avstralijski-vcheni-zaproponuvali-zodnorazovih-masok-robiti-dorogi

27. How digital reinventors are pulling away from the pack. McKinsey\&Company. (2017). Retrieved from: https://www.mckinsey.com/busines s-functions/mckinsey-digital/ourinsights/how-digital-reinventorsare-pulling-away-from-the-pack.

28. How COVID-19 has pushed companies over the technology tipping point-and transformed business forever. McKinsey\&Company. (2020) Retrieved from: https://www.mckinsey.com/busines s-functions/strategy-and-corporatefinance/our-insights/how-covid-19has-pushed-companies-over-thetechnology-tipping-point-andtransformed-business-forever

29. The Importance of Creating a Culture of Experimentation. RunRun.it. (2019). Retrieved from: https://blog.runrun.it/en/cultureof-experimentation/

30. Zozul'ov A.V., Kubishina N.S. ed. Solntsev S. O. Marketing. (2011). Kyiv: Znannia; Moscow: Rybari [in Ukrainian] . 